INDONESIAN JOURNAL OF NURSING AND MIDWIFERY

\title{
Characteristic Of Demographic Neuropathy Diabetic Perifer In The Agriculture Area
}

Ana Nistiandani ${ }^{1}$, Lantin Sulistyorini ${ }^{2}$, Nuril Fauziah ${ }^{3}$ Muhammad Fakhrur Rozsy ${ }^{4}$

\author{
${ }^{1-2}$ Lecturer in Faculty of Nursing, Jember University \\ ${ }^{3-4}$ Students in Faculty of Nursing, Jember University \\ Email: nistiandani@unej.ac.id
}

\begin{abstract}
Abstrak
Kabupaten Jember merupakan daerah yang unggul di bidang agricultural. Keunggulan di bidang pertanian, bertolak belakang dengan kondisi kesehatan masyarakatnya, yaitu adanya prevalensi penyakit Diabetes Mellitus (DM) yang tinggi. Hal ini dikaitkan dengan kemungkinan adanya paparan pestisida yang seringkali digunakan dalam bidang pertanian. DM menyebabkan berbagai komplikasi seperti, neuropati perifer. Sejauh ini karakterisik demografi diabetisi dengan neuropati perifer, masih jarang tersentuh untuk diteliti. Penelitian ini bertujuan untuk menganalisis karekteristik demografi neuropati perifer diabetik di wilayah pertanian Kabupaten Jember. Jenis penelitian ini adalah deskriptif dengan pendekatan cross sectional. Tehnik sampling yang digunakan adalah consecutive sampling. Jumlah responden dalam penelitian ini sebanyak 102 diabetisi. Instrumen yang digunakan adalah modifikasi dari MNSI (Michigan Neuropathy Screening Instrument) dan MDNS (Michigan Diabetic Neuropathy Score). Analisis dilakukan dengan univariat, yang disajikan dalam bentuk Table distribusi frekuensi dan cross tabulation. Hasil penelitian ini menunjukkan neuropati lebih banyak dialami oleh perempuan (53,9\%), memiliki penyakit penyerta (68,6\%), kategori usia dewasa tengah (71,6\%), kadar GDS 90-199 mg/dL (57,8\%), dan lama menderita $D M \geq 1$ s.d 5 tahun (58,8\%). Sebagian kecil diabetisi yang mengalami neuropati perifer memiliki riwayat DFU (9,8\%) dan riwayat merokok $(32,4 \%)$. Dengan demikian dibutuhkan adanya upaya promotif dan preventif dari pelayanan kesehatan primer kepada diabetisi, khususnya di wilayah pertanian Kabupaten Jember.
\end{abstract}

Kata Kunci: diabetes mellitus, neuropati perifer, pertanian

\begin{abstract}
Jember Regency is a superior area in the agricultural sector, but it is contrary to the health conditions of the people. It was noted that Jember experienced an increase in cases of Diabetes Mellitus (DM). DM causes various complications, one of which often occurs is peripheral neuropathy. This study aims to analyze peripheral neuropathy based on the characteristics of people with diabetes in the agriculture area under the auspices of the Health Department of Jember Regency. This type of research is descriptive with the cross-sectional approach. The sampling technique used is consecutive sampling. The number of respondents in this study was 102 people with diabetes. The instrument used was a modification of the MNSI (Michigan Neuropathy Screening Instrument) and MDNS (Michigan Diabetic Neuropathy Score). Univariate analysis is performed, which is presented in the form of frequency distribution tables and cross-tabulation. The results of this study indicate that all respondents experienced peripheral neuropathy (100\%) in the mild (43.1\%), moderate (44.2\%), and severe (12.7\%) categories. Domination of neuropathy by women (53.9\%), has comorbidities (68.6\%), middle adult age categories (71.6\%), blood glucoses $90-199 \mathrm{mg} / \mathrm{dL}$ (57.8\%), and duration of $D M \geq 1$ to 5 years (58.8\%). A small percentage of people with diabetes who have peripheral neuropathy have a history of DFU (9.8\%) and
\end{abstract}


a history of smoking (32.4\%). This nursing intervention is needed to prevent worsening of peripheral neuropathy.

Keyword: agriculture, diabetes mellitus, peripheral neuropathy.

Article info:

Article submitted on October 10, 2019

Articles revised on November 05, 2019

Articles received on November 22, 2019

DOI: $h$ ttp://dx.doi.org/10.21927/jnki.2019.7(3).201-210

\section{INTRODUCTION}

Jember Regency is an agricultural area, where around $51 \%$ of the area and its population work in agriculture (1). One of the highest plantation yields is tobacco (ILO Jakarta, 2007). Jelbuk and Tempurejo Districts are areas in Jember Regency which have extensive agricultural land $(3,4)$.

Jember's excellence in agriculture is inversely proportional to the health conditions of its people. Where reports of chronic diseases such as Diabetes Mellitus (DM) an increase in the number of visits between $2016(10,941)$ to 36,834 visits in 2018 (5). This is related to the possibility of exposure to pesticides which are often used in agriculture. Reinforced by previous research which states that exposure to pesticides can affect beta cells in producing the hormone insulin, so that blood glucoses become high and DM will occur (6).

Complications that are often experienced by people with DM are peripheral nerve damage (peripheral neuropathy) and the incidence of amputations as much as $40 \%-60 \%$ (7). Peripheral neuropathy as a manifestation of peripheral nerve damage is autonomic, sensory, and motoric $(8,9)$. The problem of peripheral nerve damage in Indonesia has not been great managing, which often ends in disability and death (Purwanti \& Maghfirah, 2016). Due to nerve damage causing a decrease in sensation, leg skin becomes dry, fissures are formed, calluses of muscle atrophy, changes in shape, and pressure distribution will be disrupted, causing an increased incidence of injuries (diabetic ulcer) (11).

Based on the previous description, it is necessary to check to determine the damage to peripheral nerves in DM clients, especially in agricultural areas. Given that farmers become one of the jobs that are at risk of developing DM and its complications, such as peripheral neuropathy. So far, there have been many studies on peripheral neuropathy, but related to the description of Peripheral Neuropathy clients based on their demographic characteristics in the plantation area is still rarely touched. The purpose of this study was to analyze the description of peripheral neuropathy of DM clients based on demographic characteristics (age, sex, duration of DM, current blood sugar check results, smoking history, history of comorbidities, amputation history, and DFU history) in the Jember agricultural area.

\section{MATERIALS AND METHODS}

This study used a cross-sectional design. This study was carried out in the agriculture Area of Jember, which was under the auspices of the Jember Regency Health Office. These areas include Jelbuk Health Center and Sukorambi Jember Health Center. The population in this study was 1,373 people with diabetes. A consecutive sampling technique was used to select the samples of 102 people with diabetes. Sample selection was based on 
specific characteristics. Inclusion criteria set by researchers include:

a. People with diabetes $>18$ years

b. People with diabetes who do not have active DFU

c. People with diabetes who did not experience amputation in both legs.

This research instrument modification questionnaire that has been testing for validity \& reliability is the MNSI (Michigan Neuropathy Screening Instrument) and MDNS (Michigan Diabetic Neuropathy Score). The research instrument is in the Indonesian version, which has been tested for validity and reliability (12). The validity test results show that the $r$ count is 0.371 0.765 ( $r$ table 0.361 ). The reliability test results showed that the Alpha Cronbach value of 0.703 . It can be concluded that the questionnaire used is valid and reliable. The tools used in this study include: Glucotest, monofilament tests, $128 \mathrm{~Hz}$ tuning forks, prick pins, and reflex hammers. The results of the study were analyzed univariately. Data was present in the form of a frequency distribution table. Besides that, it was also carried out cross-tabulation to see the representation of peripheral neuropathy based on demographic characteristics. The legal aspects of this research ethics were approving the Health Research Ethics Committee (KEPK) of the Faculty of Dentistry, University of Jember. This study was carried out for one year from the writing of the proposal to the publication of the article, as well as the preparation of a draft book on Diabetes Mellitus.

\section{RESULT AND DISCUSSION}

\section{Demographic Characteristics of people with} diabetes

Table 1 shows that the majority of respondents who suffer from DM are experienced in the middle adult age category $(71.6 \%)$, with a long time of suffering more than 5 years (95.1\%), and have a history of comorbidities (68.6\%).
Table 1. Demographic Characteristics

\begin{tabular}{|c|c|c|}
\hline Respondent Category & Frequency & $\begin{array}{c}\text { Percentage } \\
(\%)\end{array}$ \\
\hline \multicolumn{3}{|l|}{ Age (years) } \\
\hline $\begin{array}{l}\text { Early adulthood }(\geq 25-\leq \\
40)\end{array}$ & 12 & 11,8 \\
\hline Middle adult $(\geq 41-<60)$ & 73 & 71,6 \\
\hline $\begin{array}{l}\text { Late adulthood }(\geq 60-< \\
65)\end{array}$ & 17 & 16,7 \\
\hline \multicolumn{3}{|l|}{ Sex } \\
\hline Male & 47 & 46,1 \\
\hline Female & 55 & 53,9 \\
\hline \multicolumn{3}{|l|}{ Duration of DM (years) } \\
\hline$<1$ & 5 & 4,9 \\
\hline $1-5$ & 60 & 58,8 \\
\hline$>5$ & 37 & 36,3 \\
\hline \multicolumn{3}{|l|}{ Blood glucoses } \\
\hline$<90 \mathrm{mg} / \mathrm{dL}$ & 5 & 4,9 \\
\hline $90-199 \mathrm{mg} / \mathrm{dL}$ & 59 & 57,8 \\
\hline$\geq 200 \mathrm{mg} / \mathrm{dL}$ & 38 & 37,3 \\
\hline \multicolumn{3}{|l|}{ History of Smoking } \\
\hline Yes & 69 & 67,6 \\
\hline No & 33 & 32,4 \\
\hline \multicolumn{3}{|l|}{$\begin{array}{l}\text { History of comorbidities/ } \\
\text { Complication }\end{array}$} \\
\hline Yes & 70 & 68,6 \\
\hline No & 32 & 31,4 \\
\hline \multicolumn{3}{|l|}{$\begin{array}{l}\text { Types of comorbidities/ } \\
\text { Complication }\end{array}$} \\
\hline Hipertension & 61 & 59,8 \\
\hline Stroke & 5 & 4,9 \\
\hline Coronary heart disease & 0 & 0 \\
\hline CKD & 2 & 2 \\
\hline Etc.. & 2 & 2 \\
\hline \multicolumn{3}{|l|}{ History of DFU } \\
\hline Yes & 10 & 9,8 \\
\hline No & 92 & 90,2 \\
\hline Total & 102 & 100 \\
\hline
\end{tabular}

\section{Levels of Peripheral Neuropathy}

Table 2 shows that all respondents experienced peripheral neuropathy $(100 \%)$ in the mild category $(43.1 \%)$, the moderate category $(44.2 \%)$, and the severe category $(12.7 \%)$.

Table 2. Frequency Distribution of levels Peripheral Neuropathy

\begin{tabular}{lcc}
\hline Result of assasment & Frequency & Percentage (\%) \\
\hline Without neuropathy & 0 & 0 \\
Mild neuropathy & 44 & 43.1 \\
Moderate neuropathy & 45 & 44.2 \\
Severe neuropathy & 13 & 12.7 \\
\hline \multicolumn{1}{c}{ Total } & 102 & 100 \\
\hline
\end{tabular}


Overview of Peripheral Neuropathy based on Demographic Characteristic People with Diabetes

Analysis of Peripheral Neuropathy with Gender

Table 3 shows that women had more peripheral neuropathy events than men (53.9\%).

Table 3. Peripheral Neuropathy with Genders

\begin{tabular}{cccc}
\hline \multirow{2}{*}{$\begin{array}{c}\text { Levels of } \\
\text { Peripheral } \\
\text { Neuropathy }\end{array}$} & Male & Female & \multirow{2}{*}{ Total } \\
\cline { 2 - 4 } No & 0 & 0 & 0 \\
Yes & 47 & 55 & $\mathbf{1 0 2}$ \\
& $(46,1 \%)$ & $(53,9 \%)$ & $(\mathbf{1 0 0 \% )}$ \\
\hline \multicolumn{1}{c}{ Total } & $\mathbf{4 7 ( 4 6 , 1 \% )}$ & $\mathbf{5 5 ( 5 3 , 9 \% )}$ & $\mathbf{1 0 2 ( 1 0 0 \% )}$ \\
\hline
\end{tabular}

\section{Analysis of Peripheral Neuropathy with Age}

Table 4 shows that the criteria for early adulthood had fewer neuropathy events compared to middle adulthood (71.6\%) and late adulthood (16.7\%).

Table 4. Peripheral Neuropathy with age

\begin{tabular}{lcccc}
\hline $\begin{array}{l}\text { Levels of } \\
\text { Peripheral } \\
\text { Neuropathy }\end{array}$ & \multicolumn{3}{c}{ Age (years) } & \\
\cline { 2 - 4 } & $\mathbf{1 8 - 4 4}$ & $\mathbf{4 5 - 6 5}$ & $>65$ & Total \\
\hline No & 0 & 0 & 0 & 0 \\
Yes & 12 & 73 & 17 & 102 \\
& $(11,8 \%)$ & $(71,6 \%)$ & $(16,7 \%)$ & $(100 \%)$ \\
\hline \multicolumn{1}{c}{ Total } & 12 & 73 & 17 & 102 \\
& $(11,8 \%)$ & $(71,6 \%)$ & $(16,7 \%)$ & $(100 \%)$ \\
\hline
\end{tabular}

\section{Analysis of Peripheral Neuropathy with} Comorbidities/ Complication

Table 5 shows that peripheral neuropathy is more commonly experienced by DM clients who have as many comorbidities / complications $(68.6 \%)$.
Analysis of Peripheral Neuropathy with Duration of Diabetes Mellitus

Table 6 shows that peripheral neuropathy tends to be experienced by DM clients who suffer from DM s 1 to 5 years (58.8\%) and more than five years $(36.3 \%)$.

Table 6. Peripheral Neuropathy with Duration of DM

\begin{tabular}{lcccc}
\hline Levels of & \multicolumn{3}{c}{ Duration of DM (years) } & \\
\cline { 2 - 4 } $\begin{array}{c}\text { Peripheral } \\
\text { Neuropathy }\end{array}$ & $<1$ & $1-5$ & $>5$ & Total \\
\hline No & 0 & 0 & 0 & 0 \\
Yes & 5 & 60 & 37 & 102 \\
& $(4,9 \%)$ & $(58,8 \%)$ & $(36,3 \%)$ & $(100 \%)$ \\
\hline \multicolumn{1}{c}{ Total } & 5 & 60 & 37 & 102 \\
& $(4.9 \%)$ & $(58,8 \%)$ & $(36,3 \%)$ & $(100 \%)$ \\
\hline
\end{tabular}

\section{Analysis of Peripheral Neuropathy with Blood glucoses}

Table 7 shows that respondents who had blood glucose in the range of $90-199 \mathrm{mg} / \mathrm{dL}$ had a higher incidence of neuropathy as many as 59 people $(57.8 \%)$.

Table 7. Peripheral Neuropathy with Blood glucoses

\begin{tabular}{lcccc}
\hline Levels of & \multicolumn{3}{c}{ Blood glucoses } & \\
\cline { 2 - 4 } $\begin{array}{l}\text { Peripheral } \\
\text { Neuropathy }\end{array}$ & $<90 \mathrm{mg} /$ & $90-199$ & $>199$ & Total \\
\hline No & 0 & $\mathrm{mg} / \mathrm{dl}$ & $\mathrm{mg} / \mathrm{dl}$ & \\
Yes & 5 & 0 & 0 & 0 \\
\multicolumn{1}{c}{ Total } & 5 & 59 & 38 & 102 \\
& $(4.9 \%)$ & $(57,8 \%)$ & $(37,3 \%)$ & $(100 \%)$ \\
\hline
\end{tabular}

\section{Analysis of Peripheral Neuropathy with a} smoking history

Table 8 shows that clients who have no history of smoking have a higher incidence of

Table 5. Peripheral Neuropathy with Comorbidities/ Complication

\begin{tabular}{|c|c|c|c|c|c|c|c|}
\hline \multirow{2}{*}{$\begin{array}{l}\text { Levels of } \\
\text { Peripheral } \\
\text { Neuropathy }\end{array}$} & \multicolumn{6}{|c|}{ Comorbidities/ Complication } & \multirow[t]{2}{*}{ Total } \\
\hline & No Disease & Hipertension & Stroke & $\begin{array}{c}\text { Coronary heart } \\
\text { disease }\end{array}$ & CKD & Etc & \\
\hline No & 0 & 0 & 0 & 0 & 0 & 0 & 0 \\
\hline Yes & $\begin{array}{c}32 \\
(31,4 \%)\end{array}$ & $\begin{array}{c}61 \\
(59,8 \%)\end{array}$ & $\begin{array}{c}5 \\
(4,9 \%)\end{array}$ & 0 & $\begin{array}{c}2 \\
(2 \%)\end{array}$ & $\begin{array}{c}2 \\
(2 \%)\end{array}$ & $\begin{array}{c}102 \\
(100 \%)\end{array}$ \\
\hline Total & $32(31,4 \%)$ & $\begin{array}{c}61 \\
(59,8 \%)\end{array}$ & $\begin{array}{c}5 \\
(4,9 \%)\end{array}$ & 0 & $\begin{array}{c}2 \\
(2 \%)\end{array}$ & $\begin{array}{c}2 \\
(2 \%)\end{array}$ & $\begin{array}{c}102 \\
(100 \%)\end{array}$ \\
\hline
\end{tabular}


neuropathy compared to clients who smoke as many as 69 people $(67.6 \%)$.

Table 8. Peripheral Neuropathy with a smoking history

\begin{tabular}{|c|c|c|c|}
\hline \multirow{2}{*}{$\begin{array}{l}\text { Levels of } \\
\text { Peripheral } \\
\text { Neuropathy }\end{array}$} & \multicolumn{2}{|c|}{ History of Smoking } & \multirow[b]{2}{*}{ Total } \\
\hline & No & Yes & \\
\hline No & 0 & 0 & 0 \\
\hline Yes & $\begin{array}{c}69 \\
(67,6 \%)\end{array}$ & $\begin{array}{c}33 \\
(32,4 \%)\end{array}$ & $\begin{array}{c}102 \\
(100 \%)\end{array}$ \\
\hline Total & $\begin{array}{c}69 \\
(67,6 \%)\end{array}$ & $\begin{array}{c}33 \\
(32,4 \%)\end{array}$ & $\begin{array}{c}102 \\
(100 \%)\end{array}$ \\
\hline
\end{tabular}

\section{Analysis of Peripheral Neuropathy and DFU} History

Table 9 shows that ten respondents $(9.8 \%)$ who had a history of DFU had peripheral neuropathy.

Table 9. Peripheral Neuropathy with DFU history

\begin{tabular}{lccc}
\hline Levels of & \multicolumn{2}{c}{ History of DFU } & \\
\cline { 2 - 3 } $\begin{array}{c}\text { Peripheral } \\
\text { Neuropathy }\end{array}$ & No & Yes & Total \\
\hline No & 0 & 0 & \\
Yes & 92 & 10 & 102 \\
& $(90,2 \%)$ & $(9,8 \%)$ & $(100 \%)$ \\
\hline \multicolumn{1}{c}{ Total } & 92 & 10 & 102 \\
& $(90,2 \%)$ & $(9,8 \%)$ & $(100 \%)$ \\
\hline
\end{tabular}

\section{Characteristics of people with diabetes}

In this study, (Table 1) it was found that more women experience DM, namely 55 people with diabetes (53.9\%). By previous studies and reports from (RISKESDAS) from 20072013 , it shows that the proportion of people with diabetes mellitus is higher in women (13) (14). Women are more at risk of developing DM due to factors such as body fat levels, hormones, and psychological stress (15). More body fat than men makes women prone to obesity (16). More giant fat cells in the body result in inadequate response to insulin (17). Besides female hormonal conditions such as premenstrual syndrome, post-menopause which makes body fat distribution quickly accumulated due to the hormonal process so that women are more at risk of developing DM $(15,17)$.
Increased age is one of the risk factors for DM. The results of this study indicate that people with diabetes are dominated by the middle and late adult age categories of 90 people $(88.3 \%)$ (Table 1). In theory, the increasing age of eating the body will decrease its function as well as the ability of $\beta$ cells to produce insulin to metabolize glucose $(18,19)$. Likewise, the results of primary health research in 2014 showed that the proportion of people with diabetes increased with age and the category of adult age was in the highest proportion (14).

This study shows that people with diabetes are dominated by long sufferers of more than five years $(95.1 \%)$ (Table 1$)$. In accordance with the study (13) that the majority of people with diabetes who went to the hospital had suffered more than five years. It is logical if the distribution of people with diabetes in this study were the majority of people with diabetes with long DM> 5 years $(20)$.

The majority of people with diabetes have a smoking history of 69 people $(67.6 \%)$ (Table 1 ). In line with the results research Chintya Halim (2017), it is stated that the number of cigarettes smoked each day, the blood glucose levels will increase. One of the cigarette content, nicotine, influences blood glucoses. Nicotine causes resistance to insulin receptors and decreases its secretion in $\beta$ cells (22). Thus, it can be seen that smoking behavior is a risk factor for diabetes mellitus.

People with diabetes who have average blood glucoses in the normal range are only $(4.9 \%)$ (Table 1). Other studies have shown that DM patients have a high average blood glucose level with poor blood glucose control (23). Inadequate blood glucose is influenced by patients who do not regularly control blood glucoses (24). How to prevent complications from $\mathrm{DM}$, it requires treatment and various treatments for life (Association American Diabetes, 2011; Lewis, Dirksen, Heitkemper, Bucher, \& Camera, 
2011). Among others, controlling blood glucoses, regular physical activity, adherence to taking medication, and dietary restrictions (27). The various treatments that must be performed are long-term stressors for DM patients (28). It can be concluded that controlling blood glucoses for people with diabetes is not an easy process, so it is rare to find people with diabetes who can control it well.

This study shows that the majority of people with diabetes have concomitant diseases, as many as 70 people (68.6\%) (Table 1$)$. In line with the research of Nistiandani et al., (2018) the majority of people with diabetes have comorbidities. Chronic hyperglycemia can cause ischemia in various organs and cause other diseases such as hypertension and diabetic ulcers (29). Likewise, the results of this study indicate that hypertension is the most frequent accompanying disease experienced by people with diabetes and as many as ten people (9.8\%) have a history of DFU.

\section{Levels of Peripheral Neuropathy}

All people with diabetes in the agricultural area who were respondents experienced peripheral neuropathy (100\%) (Table 2 ). This study showed that neuropathy was most experienced in the mild $(43.1 \%)$ and moderate $(44.2 \%)$ categories. While the weight category experienced by a small number of people with diabetes is $12.7 \%$. Corresponds to previous studies which showed that the mild and moderate categories had the highest percentage compared to the severe neuropathy category (30),(12).

Peripheral neuropathy experienced by people with diabetes can be founding in different levels of neuropathy experienced by clients ranging from mild, moderate to severe (12). This difference can occur, one of which is because there are differences in demographic characteristics that will affect the disease process of the people with diabetes.

\section{Overview of Peripheral Neuropathy based on Demographic Characteristics}

The results showed that the incidence of peripheral neuropathy was more experienced by women (Table 3). By some previous studies, it is stated that about $53 \%$ more who experience peripheral neuropathy are women $(30,31)$. Contrary to this result, it is mentioned that it is precisely the male sex more experiencing diabetic peripheral neuropathy (32). Researcher's assumption, differences in the results of this study can occur because, in this study, the number of female respondents is higher than that of men. Thus, it was concluded that men and women had the same chance of experiencing peripheral neuropathy.

This study shows that the incidence of diabetic peripheral neuropathy is more experienced by middle and late adult age categories (Table 4). Corresponding to this states that the average person with diabetes who has neuropathy in middle adulthood is around 51 years (30). Strengthened by research in Manado states that the age range of 46-65 years is the most frequent category of diabetic peripheral neuropathy (33). Old age is related to the accumulation of damage due to free radicals such as increased enzyme activity which ends with tissue damage and decreased bodily functions (34). The more mature age of someone with DM it will have great potential in experiencing diabetic peripheral neuropathy. This is caused by a decrease in bodily functions that are increasingly down in late adulthood.

The results showed that hypertension had the highest percentage of complications experienced by DM clients with diabetic peripheral neuropathy (Table 5). Other research states that hypertension has a significant relationship with the incidence of diabetic neuropathy. Most groups of cases with diabetic neuropathy have a history of hypertension of $66.67 \%$ (35). As much as $51.8 \%$ of the proportion of DM clients 
experiencing hypertension, this will affect the incidence of neuropathy due to DM (33). Diabetes complications that often occur are hypertension, the incidence of hypertension itself causes thickening of the blood vessels resulting in narrowing of the diameter of blood vessels. The narrowing of blood vessels will affect the process of transporting metabolism in the disrupted blood vessels, and blood glucose levels will be disrupted (36). So that if someone who has DM and hypertension complications, the possibility of experiencing diabetic peripheral neuropathy disorders is higher due to the ineffectiveness in maintaining blood glucose balance due to the narrowing of blood vessel diameter.

The results showed that clients who experience diabetic peripheral neuropathy most occur in DM clients who have suffered for approximately 1-5 years (Table 6). In line with research conducted by Hutapea et al., (2016) states that DM clients who have the most peripheral neuropathy, more or less have experienced DM 1-5 years. Supported by other studies mention that the average length of DM clients who experience peripheral neuropathy is around four years so that someone who has had diabetes for a long time then the likelihood of diabetic peripheral neuropathy will be even higher (37). The longer a person suffers from DM, the balance of glucose levels in the blood will be disrupting, and if it occurs in a long duration, then it will damage the blood vessels (38).

The results showed that GDS levels> $199 \mathrm{mg} / \mathrm{dL}$ had a relatively high incidence of neuropathy (Table 7). Confirmed by research from the Suri et al. (2015) states that in a state of hyperglycemia with a GDS above $200 \mathrm{mg} / \mathrm{dL}$, people with diabetes are at risk of experiencing more significant nerve fiber damage, especially nerves that are in the distal part. However, diabetic peripheral neuropathy in this study occurred in the GDS range of $90-199 \mathrm{mg} / \mathrm{dL}$. This research is in accordance with previous studies that show that the incidence of neuropathy is more common in people with diabetes who have GDS levels in the range of $90-199 \mathrm{mg} / \mathrm{dL}$ (12). According to researchers, people with diabetes with GDS 90-199 mg / dL are considered hyperglycemic. Diabetic peripheral neuropathy is one of the complications resulting from uncontrolled DM blood glucoses (37).

The results showed that the majority of people with diabetes had a history of not smoking (Table 8). This study is different from previous research which states that smoking can be associated with an increased risk of diabetic neuropathy in people with diabetes (39). Free radicals in cigarettes result in the formation of plaques in blood vessels, and if they are carrying out continuously, it will cause damage to blood vessels and circulation which will worsen the condition of people with diabetes and cause complications (40).

Wiatma \& Amin (2019) explained that there was a significant relationship between smoking and blood glucoses due to cigarette content, namely nicotine. Nicotine causes resistance to insulin receptors and decreases its secretion in $\beta$ cells (22). Researcher's assumption, differences in the results of this study can occur because, in this study, the number of respondents with a history of smoking is less than the number of respondents who do not smoke. Thus, it can be concluded that respondents who smoke and do not smoke have the same chance of experiencing peripheral neuropathy.

The results showed that ten respondents who had a history of DFU experienced peripheral neuropathy (Table 9). It can be explained that in the condition of chronic hyperglycemia, it will cause ischemia in various organs and can cause diabetic ulcers (29). According to Sulistiari's reasearch (2013) that the factors that influence ulcers are neuropathy.

Peripheral neuropathy is the primary pathogenesis of DFU. The loss of pain and 
temperature sensation due to sensory neuropathy causes a loss of alertness to trauma or foreign bodies, which in turn results in unconscious injuries and worsens due to decreased pressure (43). Damage to the innervation of the intrinsic muscles of the foot due to motor neuropathy causes an imbalance between leg flexion and extension and foot deformity, which then causes changes in the distribution of pressure on the soles of the feet which in turn triggers callus. A callus that is not managed correctly will be a source of trauma to the foot. Autonomic neuropathy causes a decrease in the function of sweat glands and sebum. The foot will lose its natural ability to moisturize the skin; the skin becomes dry and cracked so that it is easily infected (43).

\section{CONCLUSION AND RECOMMENDATION}

Demographic characteristics of people with diabetes in agricultural areas undergoing peripheral neuropathy examinations include age, sex, duration of illness, history of comorbidities/ complications, current blood glucoses, smoking history, and DFU history. Peripheral neuropathy experienced by all study respondents 102 people with diabetes (100\%). The neuropathies included mild $(43.1 \%)$, moderate $(44.2 \%)$, and severe $(12.7 \%)$. Women more commonly experienced neuropathy (53.9\%), has comorbidities $(68.6 \%)$, middle adult age categories (71.6\%), blood glucoses 90-199 mg / dL (57.8\%), and duration of $\mathrm{DM} \geq 1$ to 5 years (58.8\%). A small percentage of people with diabetes who have peripheral neuropathy have a history of DFU $(9.8 \%)$ and a history of smoking (32.4\%).

The majority of people with diabetes have complications of peripheral neuropathy. Thus it is necessary to promote and preventive efforts from primary health care for people with diabetes, especially in the agricultural area of Jember Regency. This effort was made to avoid the worsening of peripheral neuropathy, such as diabetic ulcer, amputation, and even death.

\section{REFERENCES}

1. Jember PK (PEMKAB). Potensi dan Produk Unggulan Jawa Timur. Jember; 2012.

2. ILO JAKARTA. Pekerja Anak Di Industri Tembakau Jember. Jakarta; 2007. 54 p.

3. Pangestu EN. Laporan praktikum komoditas tembakau. 2017.

4. Petrina JM. Peran Kelompok Tani Dan Pola Kemitraan Petani Tembakau Dusun Tenggir Timur Desa Jelbuk Kecamatan Jelbuk. Jember; 2015.

5. Dinas Kesehatan Kab. Jember. Laporan PTM 2017. Jember; 2017.

6. Saputri EG, Setiani O, YD NA, Budiyono. Hubungan Riwayat Pajanan Pestisida Dengan Kejadian Diabetes Melitus Tipe 2 Pada Petani Penyemprot Di Kecamatan Ngablak Kabupaten Magelang. J Kesehat Masy. 2018;6(1):645-54.

7. World Health Organization. Diabetes Country Profiles. 2016;2016.

8. Tesfaye S, Boulton AJM, Dyck PJ, Freeman $R$, Horowits $M$, Kempler $P$, et al. Diabetic Neuropathies: Update on Definitions, Diagnostic Criteria , Estimation of Severity , and Treatments. care.diabetesjournals.org. 2010;33(10):2285-93.

9. Alport AR, Sander HW. Clinical Approach to Peripheral Neuropathy: Anatomic Localization and Diagnostic Testing. Contin Lifelong Learn Neuro. 2012;2(18):13-38.

10.Purwanti LE, Maghfirah S. Faktor Risiko Komplikasi Kronis (Kaki Diabetik) Dalam Diabetes Mellitus Tipe 2. Indones J Heal Sci. 2016;7(1):26-39.

11.Smeltzer, S.C \& Bare BG. Brunner \& Suddarth's Textbook of Medical Surgical. 10 th Edit. USA: Nursing: Lippincott Williams \& Wilkins.; 2008.

12.Rosyida K. Gambaran Neuropati Perifer Pada Diabetisi Di Wilayah Kerja Puskesmas Kedungmundu Semarang. Universitas Diponegoro; 2016. 
13.Nistiandani A, Juniarto AZ, Dyan NS. Stages Of Grief Dan Depresi Pada Pasien Diabetes Mellitus. Universitas Diponegoro; 2018.

14.Kementerian Kesehatan RI. Pusat Data dan Informasi Kementerian Kesehatan RISituasi dan Analisis Diabetes. Pusat Data dan Informasi Kementerian Kesehatan RI. JAKARTA; 2014.

15.Kautzky-Willer A, Harreiter J, Pacini G. Sex and gender differences in risk, pathophysiology and complications of type 2 diabetes mellitus. Endocr Rev. 2016;37(3):278-316.

16.Pieter HZ, Janiwarti B, Saragih M. Pengantar Psikopatologi untuk Keperawatan. Edisi 1. Jakarta: Kencana; 2011.

17. Wahyuni S, Alkaff RN. Diabetes Mellitus Pada Perempuan Usia Reproduksi Di Indonesia Tahun 2007. J Kesehat Reproduksi. 2013;3(1):46-51.

18. Betteng R, Pangemanan D, Mayulu N. Analisis Faktor Resiko Penyebab Terjadinya Diabetes Melitus Tipe 2 Pada Wanita Usia Produktif Dipuskesmas Wawonasa. J e-Biomedik (eBM. 2014; Volume 2,:9.

19. Iroth GSN, Kandou GD, Malonda NSH. Hubungan Antara Umur Dan Pola Makan Dengan Kejadian Diabetes Melitus Tipe 2 Pada Pasien Rawat Jalan Di Wilayah Kerja Puskesmas Tenga Kecamatan Tenga. Media Kesehat. 2017;9(3).

20.Safitri D. Hubungan Antara Tingkat Depresi Dengan Kualitas Hidup Pada Pasien Diabetes Melitus Tipe II Di Rumah Sakit Islam Surakarta. Universitas Muhamadiyah Surakarta; 2013.

21. Chintya Halim. Pengaruh Perilaku Merokok Terhadap Kadar Glukosa Darah: Tinjauan Jumlah Batang Rokok Yang Dihisap Pada Pria Perokok Bersuku Tionghoa Indonesia. Universitas Sanata Dharma Yogyakarta; 2017.

22. Liu T, Chen W, David SP, Tyndale RF, Wang $\mathrm{H}$, Chen $\mathrm{Y}$, et al. Interaction between heavy smoking and CYP2A6 genotypes on type 2 diabetes and its possible pathways. Eur J Endocrinol. 2011;2007(June 2007):961-7.

23. Amir SMJ, Wungouw H, Pangemanan D. Kadar Glukosa Darah Sewaktu Pada Pasien Diabetes Melitus Tipe 2 Di Puskesmas Bahu Kota Manado. J e-Biomedik. 2015;3(April):1.

24. Rachmawati N, Dyan NS. Gambaran Kontrol dan Kadar Gula Darah pada Pasien Diabetes Melitus di Poliklinik Penyakit Dalam RSJ Prof. Dr. Soerojo Magelang. 2015;01.

25. Lewis SL, Dirksen SR, Heitkemper MM, Bucher L, Camera IM. Medical Surgical Nursing: Assesment and Management of Clinical Problem. 8th ed. St. Louis: Mosby, Inc.; 2011.

26. ASSOCIATION AMERICAN DIABETES. Standards of Medical Care in Diabetes. Diabetes Care. 2011;34(SUPPLEMENT 1):1-51.

27. Maghfira S, Sudiana IK, Widyawati IY. Relaksasi Otot Progresif Terhadap Stres Psikologis Dan Perilaku Perawatan Diri Pasien Diabetes Mellitus Tipe 2. J Kesehat Masy. 2013;8(2):113-20.

28. Rondhianto. Pengaruh Diabetes Self Management Education Dalam Discharge Planning Terhadap Self Care Behavior Pasien Diabetes Mellitus Tipe 2. J Keperawatan Soedirman (The Soedirman J Nursing). 2012;7(3):133-41.

29. Arsono S. Diabetes Mellitus Sebagai Faktor Risiko Kejadian Gagal Ginjal Terminal. Universitas Diponegoro Semarang; 2005.

30. Desnita R. Hubungan derajat neuropati dengan keseimbangan fungsional pada pasien neuropati diabetik. J Keperawatan Muhammadiyah. 2017;2(2).

31. Syafi'i MR. Gambaran Klinis Neuropati Perifer Pada Penyandang Diabetes Melitus Di Wilayah Puskesmas Purwosari. Universitas Muhammadiyah Surakarta; 2018. 
32. Tanhardjo J, Pinzon RT, Sari LK. Perbandingan Rerata Kadar Hba1c Pada Pasien Diabetes Melitus Dengan Neuropati Dan Tanpa Neuropati Sensori Motor. Berk IIm Kedokt Duta Wacana. 2016;01(2):127-36.

33. Hutapea FS, Kembuan MAHN, Maja Ju. Gambaran klinis neuropati pada pasien diabetes melitus di Poliklinik Neurologi RSUP Prof. Dr. R. D. Kandou periode Juli 2014 - Juni 201. J e-Clinic. 2016;4(1).

34. Prasetyo MA. Pengaruh Penambahan Alpha Lipoic Acid Terhadap Perbaikan Klinis Penderita Polineuropati Diabetika. Universitas Diponegoro Semarang; 2011.

35. Rahmawati A, Hargono A. Faktor Dominan Neuropati Diabetik Pada Pasien Diabetes Melitus Tipe 2. J Berkal Epidemiol. 2018;6(11):60-8.

36. Fadilah NA, Saraswati LD, Adi MS. Gambaran Karakteristik Dan Faktor-Faktor Yang Berhubungan Dengan Kejadian Diabetes Melitus Tipe 2 Pada Wanita (Studi di RSUD Kardinah Kota Tegal). J Kesehat Masy. 2016;4:176-83.

37. Suyanto. Gambaran karakteristik penderita neuropati perifer diabetik. J Keperawatan dan Pemikir IIm. 2017;3 (1)(Dm):1-6.
38. Yulita RF, Waluyo A, Azzam R. Pengaruh Senam Kaki Terhadap Penurunan Skor Neuropati Dan Kadar Gula Darah Pada Pasien Dm Tipe 2. J Telenursing. 2019;1:80-95.

39. Clair C, Cohen MJ, Eichler F, Selby KJ, Rigotti NaA. The Effect of Cigarette Smoking on Diabetic Peripheral Neuropathy: A Systematic Review and Meta-Analysis. J Gen Intern Med. 2015;30(8).

40. Shabira D, Harjono Y, Bustamam N. Hubungan Antara Derajat Merokok Dan Kadar Gula Darah Terhadap Resiko Terjadinya Kaki Diabetik Pada Pasien Diabetes Mellitus Pria Dirsud Ciawi Bogor. Bina Widya. 2014;25(4):162-7.

41. Wiatma DS, Amin M. Hubungan Merokok Dengan Kadar Glukosa Darah Mahasiswa Fakultas Hukum Universitas Islam Al-Azhar Tahun 2019. Universitas Islam Al-Azhar; 2019.

42. Sulistiari DA. Pengaruh Pendidikan Kesehatan Perawatan Kaki Terhadap Kepatuhan Pasien Diabetes Mellitus Tipe 2 Dalam Melakukan Perawatan Kaki Di Wilayah Kerja Puskesmas Jenggawah Kabupaten Jember. Universitas Jember; 2013.

43. Bowering CK. Diabetic foot ulcers Pathophysiology, assessment, and therapy C. Can Fam Physician •. 2014;47. 